\begin{tabular}{|c|c|c|}
\hline $\begin{array}{l}\text { UAD } \\
\text { Universitas } \\
\text { Ahmad Dahlan }\end{array}$ & $\begin{array}{c}\text { Jurnal Fokus Manajemen Bisnis } \\
\text { Volume 11, Nomor 2, September 2021, Halaman 216-229 } \\
\text { https://doi.org/10.12928/ /fokus.v11i2.4601 } \\
\text { http://journal2.uad.ac.id/index.php/fokus }\end{array}$ & $\underset{\mathrm{F} \oplus \mathrm{KUS}}{2}$ \\
\hline
\end{tabular}

\title{
SISI GELAP SMARTPHONE: FAKTOR YANG MEMPENGARUHI KETERGANTUNGAN DAN NIAT PEMBELIAN ULANG
}

\author{
Antonius Satria Hadi* \\ Universitas Widya Mataram \\ antonius_satria@widyamataram.ac.id \\ *Correspondent Author \\ Article History \\ Received 2021-08-02 \\ Revised 2021-08-09 \\ Accepted 2021-08-10 \\ Keywords \\ Convenience; \\ Social Influence; \\ Social Need; \\ Dependency; \\ In this digital era, smartphones are considered a primary need in everyday life. A \\ person's behavior that reflects the dependence on smartphones is when most of \\ their activities were spent using a smartphone. This study aims to analyze the \\ relationship among variables convenience, social influence, and social need \\ towards the dependence on smartphones. Then, this study analyzed the \\ relationship of dependence on smartphones towards repurchase intention. \\ Respondents of this study were undergraduate students in Yogyakarta who are \\ using smartphones for their daily activities. The analytical technique used in this \\ study was structural equation modeling using LISREL 10.1 software. This study \\ proposed four hypotheses then the result showed that all hypotheses were \\ accepted.
}

Repurchase Intention.

This is an open-access article under the CC-BY-SA license.

\section{Pendahuluan}

Smartphone merupakan ponsel yang memiliki teknologi lebih canggih, fitur lebih banyak, serta tampilan lebih menarik daripada telepon genggam (ponsel) biasa. Pernyataan ini didukung oleh pendapat dari para peneliti terdahulu yang menyatakan bahwa smartphone adalah telepon yang menyatukan kemampuan-kemampuan terdepan yang dapat berfungsi seperti sebuah komputer dengan menawarkan fitur-fitur seperti personal digital assistant (PDA), global positioning system (GPS), akses internet, dan email (Backer, 2010; Lian et al., 2016; Liu et al., 2020).

Smartphone bukan lagi alat komunikasi mutakhir, tetapi sekarang menjadi kebutuhan dalam kehidupan orang-orang. Bagi pengguna smartphone, ponsel adalah hal pertama yang mereka lihat di pagi hari, dan hal terakhir yang mereka lihat sebelum tidur (Ting et al., 2011). Gambar 1 di bawah memperlihatkan bahwa pengguna smartphone yang terus meningkat mulai dari tahun 2015 yang hanya sebesar hampir 30\% dari total populasi menjadi hampir 80\% pada tahun 2021 di Indonesia (Pusparisa, 2020). Hal ini dapat dikatakan bahwa durasi kontak antara pengguna dengan smartphone atau durasi penggunaan smartphone oleh pengguna (konsumen) menghabiskan waktu berjam-jam, serta cenderung relatif lama setiap hari dimanapun dan kapanpun. 


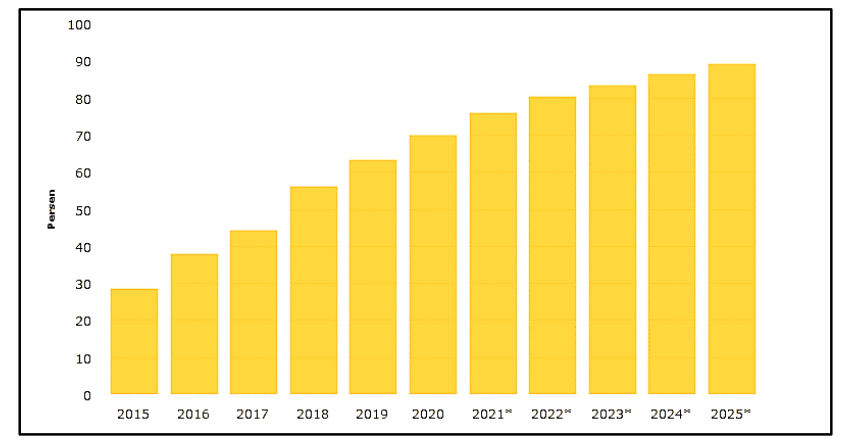

Gambar 1. Jumlah Pengguna Smartphone di Indonesia (Statista Research Department, 2020)

Perilaku seseorang yang mencerminkan sangat ketergantungan pada smartphone adalah sebagian besar aktivitas sehari-harinya cenderung dihabiskan untuk menggunakan smartphone tersebut, serta smartphone selalu dibawa kemana saja dan kapan saja. Pernyataan tersebut diperkuat oleh pendapat dari Ball-Rokeach \& Defleur (1989) yang mengemukakan bahwa semakin sering seseorang bergantung pada kebutuhan akan suatu media, maka akan semakin penting peran media tersebut dalam kehidupan seseorang dan teori ini mengidentifikasi bagaimana orang menggunakan dan menjadi tergantung pada media.

Beberapa faktor yang dapat menyebabkan perilaku ketergantungan pada smartphone antara lain yang pertama adalah kenyamanan. Kenyamanan diilustrasikan secara sederhana sebagai kondisi perasaan mengenakkan yang ada pada diri seseorang ketika menggunakan barang (dalam hal ini smartphone). Hal tersebut sesuai dengan pendapat yang dikemukakan oleh Davis et al., (1989) yang menyatakan bahwa kenyamanan adalah sejauhmana seorang individu menerima dampak setelah menggunakan teknologi agar menjadi menyenangkan dalam dirinya sendiri, terlepas dari konsekuensi kinerja yang dapat diantisipasi. Faktor kedua yang mempengaruhi ketergantungan konsumen pada smartphone adalah kebutuhan sosial. Kebutuhan sosial merupakan kebutuhan seseorang untuk berinteraksi, berkomunikasi, serta tetap ingin terhubung dengan orang lain (Tikkanen, 2009). Faktor ketiga yang mempengaruhi ketergantungan pada smartphone adalah pengaruh sosial. Pengaruh sosial merupakan cara orang lain mempengaruhi keyakinan, perasaan, dan perilaku seseorang (Mason et al., 2007).

Ketergantungan smartphone yang dipengaruhi oleh beberapa faktor seperti kenyamanan, kebutuhan sosial, dan pengaruh sosial cenderung berdampak pada munculnya niat pembelian ulang. Niat pembelian ulang merupakan niat konsumen untuk membeli kembali produk yang sama yang disebabkan oleh pengalaman positif pasca pembelian atau ketika mengkonsumsi produk tersebut. Hal tersebut sesuai dengan pendapat dari Thamrin (2003) yang menyatakan bahwa niat beli ulang yang tinggi mencerminkan tingkat kepuasan yang tinggi dari konsumen ketika memutuskan untuk mengkonsumsi ulang suatu produk.

Ketergantungan smartphone cenderung memicu munculnya niat pembelian ulang dari penggunanya. Pendapat ini didukung oleh beberapa hasil penelitian sebelumnya (Ting et al., 2011; Rahim et al., 2016; Hadi, 2020) yang menemukan bahwa konsumen dengan tingkat ketergantungan yang tinggi pada smartphone berkorelasi positif dengan perilaku konsumen pembelian masa depan. Dampak yang ditimbulkan dari perilaku ketergantungan seseorang terhadap smartphone selain niat pembelian ulang yaitu dampak positif dalam kehidupan pengguna yang berupa akses data dengan cepat, akses hiburan, bahkan komunikasi yang instan dan intensif dengan orang lain dapat diperoleh dengan cepat (Mayasari, 2010). Dampak lain yang ditimbulkan oleh perilaku ketergantungan tersebut cenderung negatif yang meliputi perilaku konsumtif, gelisah ketika tidak membawa smartphone, pola tidur terganggu, berkurangnya kontak fisik secara langsung dengan orang lain, dan sebagainya (Rice-Lincoln, 2011).

Hal lain yang menjadi fokus dalam penelitian ini adalah kontekstual penelitian. 
Mayoritas penelitian sebelumnya berkaitan dengan teori ketergantungan terhadap media radio (Hahn \& Kim, 2013; Towner \& Lego, 2016), televisi (Ho et al., 2015; Jang \& Baek, 2019), dan internet (Ognyanova \& Ball-Rokeach, 2015; Nawi et al., 2020), maka terdapat celah penelitian dalam hal konteks yaitu masih sangat sedikitnya penelitian yang mengambil konteks ketergantungan terhadap smartphone, sehingga konteks dalam penelitian ini difokuskan pada ketergantungan terhadap smartphone.

Selain itu, penelitian ini juga berusaha untuk mengisi celah teoritikal dan praktikal yaitu dalam penelitian ini mampu memverifikasi, mengkonfirmasi, dan menguatkan teori individual media dependency. Hal tersebut erat kaitannya dengan celah metodologikal yang berarti bahwa penelitian ini akan menguji alat ukur mengenai ketergantungan yang dilakukan di negara yang berbeda, maka validasi lintas negara dapat terpenuhi. Dengan demikian, penelitian ini berusaha untuk mengisi celah riset empirikal, kontekstual, teoritikal, praktikal, dan metodologikal yang sudah dipaparkan di atas.

\section{Review Literatur dan Hipotesis}

\subsection{Landasan Teori}

\subsubsection{Teori Ketergantungan Media}

Ketergantungan terhadap media bisa diukur berdasarkan teori ketergantungan media (media dependency theory). Teori ketergantungan media memperkirakan bahwa seseorang bergantung pada informasi media untuk memenuhi kebutuhan tertentu dan mencapai tujuan tertentu (Jung, 2017). Ketergantungan dapat dikatakan sebagai perilaku mengkonsumsi barang atau menggunakan jasa tertentu yang dilakukan oleh seseorang yang cenderung berlebihan dimanapun dan kapanpun secara terus menerus.

Hal ini berarti bahwa seseorang yang mengalami ketergantungan cenderung tidak mau berpisah secara fisik dengan barang dan jasa yang digunakan tersebut dimanapun dan kapanpun (Park, 2013). Sebagai contoh seseorang yang ketergantungan smartphone cenderung sebagian besar aktivitas sehari-harinya dihabiskan untuk menggunakan smartphone tersebut, dan orang tersebut cenderung tidak melakukan aktivitas sehari-hari lainnya sebagaimana mestinya (diabaikan).

Perilaku seseorang yang mencerminkan sangat ketergantungan terhadap smartphone adalah smartphone selalu dibawa kemana saja, kapan saja, bahkan ketika orang tersebut mau tidur pada malam hari (Harun et al., 2015). Hal tersebut apabila terjadi secara terus-menerus pada seseorang, maka akan berdampak negatif pada kondisi psikologis individu tersebut. Contohnya individu yang sedang menggunakan smartphone, tetapi tiba-tiba saja smartphone-nya rusak, maka orang tersebut spontan merasa bingung dan marah berlebihan, atau bahkan sampai mengalami stres akibat kejadian tersebut.

Teori ketergantungan mengatakan bahwa seseorang akan tergantung pada media dengan tujuan memenuhi kebutuhannya (Ho et al., 2015; Zhang \& Zhong, 2020). Media akan menjadi lebih penting untuk individu tersebut, apabila media itu dapat memenuhi sebagian besar atau lebih banyak kebutuhan dan keinginan penggunanya. Media juga akan memiliki pengaruh lebih banyak terhadap individu, sehingga individu tersebut dikuasai dan dikendalikan oleh media. Hal ini sesuai dengan teori-teori sebelumnya yang menekankan pada pengguna sebagai penentu media, teori ini memperlihatkan bahwa individu bergantung pada media untuk pemenuhan kebutuhan atau untuk mencapai tujuannya, tetapi individu tidak bergantung pada banyak media dengan persentase yang sama besar. Individu tetap bisa memilih media mana yang akan digunakan untuk memenuhi keinginan ataupun kebutuhannya.

Pernyataan mengenai teori ketergantungan di atas sesuai dengan pendapat para peneliti terdahulu (Chen, 2013; Lee \& Choi, 2018) yang mengemukakan bahwa semakin sering seseorang bergantung pada kebutuhan akan suatu media, maka akan semakin 
penting peran media tersebut dalam kehidupan seseorang dan teori ini mengidentifikasi bagaimana orang menggunakan dan menjadi tergantung pada media.

\subsubsection{Ketergantungan Media Tingkat Mikro}

Teori ketergantungan media yang dilihat pada tingkatan mikro adalah ketergantungan media secara individu (individual media dependency). Ketergantungan media secara individu didefinisikan sebagai suatu hubungan yang menempatkan kapasitas individu untuk mencapai tujuannya tergantung pada cara tertentu yaitu akses ke sumber daya informasi yang dikendalikan oleh media (Lee \& Choi, 2018).

Hal ini memperlihatkan betapa pentingnya media tertentu untuk individu karena individu cenderung dapat mencapai tujuan dan keinginannya jika menggunakan media tertentu. Hal tersebut berarti individu harus tergantung kepada media tertentu agar dapat memenuhi tujuannya. Apabila tidak tergantung kepada media tertentu, maka tujuannya tidak akan bisa tercapai sehingga teori ini yang memberikan dasar nyata untuk mengukur hubungan ketergantungan individu yang berkaitan dengan media tertentu (Zhang \& Zhong, 2020).

Perwujudan ketergantungan media pada level mikro seperti yang telah dipaparkan di atas mengungkapkan betapa pentingnya peran media tertentu untuk menciptakan perilaku ketergantungan. Salah satu jenis media tertentu yang dapat menimbulkan ketergantungan adalah smartphone. Smartphone merupakan ponsel paling canggih pada saat ini yang salah satu fungsinya sebagai media atau alat komunikasi.

\subsection{Hipotesis}

\subsubsection{Pengaruh Positif Kenyamanan terhadap Ketergantungan pada Smartphone}

Konsumen dapat memperoleh informasi yang berguna secara mudah dan cepat melalui internet pada smartphone-nya, memeriksa surat elektronik, dan menggunakan fasilitas obrolan dalam jaringan (Genova, 2010; Hudson, 2010). Kenyamanan konsumen diperoleh dari penggabungan ponsel biasa dan laptop ke dalam smartphone (Stephen \& Davis, 2009). Konsumen yang sudah merasa nyaman pada saat menggunakan dan setelah menggunakan smartphone-nya cenderung mengulangi aktivitas yang sama dimana saja dan kapan saja (Hahn, 2010). Ketergantungan adalah aktivitas tertentu yang dilakukan berulang-ulang (Hovart, 1989). Semakin nyaman seseorang pada saat dan setelah menggunakan smartphone-nya, maka seseorang tersebut cenderung semakin tergantung pada smartphone-nya (Ting, et. al. 2011; Harun et al., 2015). Dengan demikian hipotesis pertama adalah:

\section{$\mathrm{H}_{1}$ : Kenyamanan Berpengaruh Positif terhadap Ketergantungan pada Smartphone}

\subsubsection{Pengaruh Positif Kebutuhan Sosial terhadap Ketergantungan pada Smartphone}

Kebutuhan sosial meliputi keinginan untuk disayangi, kemitraan, persahabatan serta diterima oleh orang lain (Schiffman et al., 2009). Smartphone telah menjadi jauh lebih fleksibel, yang memungkinkan konsumen untuk meningkatkan penggunaannya untuk berkomunikasi dan menjaga hubungan yang terjadi diantara individu-individu (Lippincott, 2010). Kebutuhan sosial konsumen dapat terpenuhi melalui fitur yang ada di dalam smartphone (Raskin, 2006). Semakin tinggi kebutuhan sosial seseorang (konsumen), maka semakin tinggi pula ketergantungannya terhadap smartphone (Suki \& Suki, 2013). Dengan demikian hipotesis kedua adalah:

$\mathrm{H}_{2}$ : Kebutuhan Sosial Berpengaruh Positif terhadap Ketergantungan pada Smartphone 


\subsubsection{Dampak Positif Pengaruh Sosial terhadap Ketergantungan pada Smartphone}

Pengaruh sosial sebagai cara orang lain mempengaruhi keyakinan, perasaan dan perilaku seseorang, sehingga terdapat perubahan sikap atau perilaku, sebagai hasil dari interaksi dengan orang lain (Mason et al., 2007). Pengaruh sosial sering dianggap sebagai pemberi pengaruh yang kuat melalui pengamatan, persepsi atau antisipasi dari keputusan yang dibuat oleh orang lain, yang mempengaruhi ketergantungan konsumen (pengguna) terhadap smartphone (Suki \& Suki, 2013). Semakin tinggi pengaruh sosial dari pihak lain, maka cenderung ketergantungan terhadap smartphone semakin tinggi (Ting et al., 2011). Dengan demikian hipotesis ketiga adalah:

\section{$\mathrm{H}_{3}$ : Pengaruh Sosial Berpengaruh Positif terhadap Ketergantungan pada Smartphone}

\subsubsection{Pengaruh Positif Ketergantungan pada Smartphone terhadap Niat Pembelian Ulang}

Ketergantungan merupakan kondisi terikat pada kebiasaan yang sangat kuat, sehingga muncul perilaku kecanduan pada sesuatu (Wulandari, 2015). Smartphone sebagai suatu kebutuhan serta memiliki kecenderungan yang kuat untuk penggunaan yang tinggi secara terus menerus, yang terikat, dan tidak mau terpisah (Tian et. al., 2009). Konsumen tidak hanya memiliki pengetahuan pribadi tentang atribut tetapi juga memiliki pengalaman pribadi positif tentang bagaimana smartphone tersebut mampu memenuhi kebutuhan konsumen (Keaveney \& Parthasarathy, 2001). Oliver (1999) menyatakan bahwa respon yang diakibatkan oleh pengalaman positif masa lalu yang diterima untuk melakukan pembelian secara berulang disebut niat beli ulang. Beberapa hasil penelitian menemukan bahwa ketergantungan terhadap smartphone berpengaruh positif dan signifikan terhadap niat pembelian ulang (Ting, et al., 2011; Suki \& Suki, 2013; Vahabzadeh, et al., 2014). Dengan demikian hipotesis keempat adalah:

$\mathrm{H}_{4}$ : Ketergantungan pada Smartphone Berpengaruh Positif terhadap Niat Pembelian Ulang

\subsection{Model Penelitian}

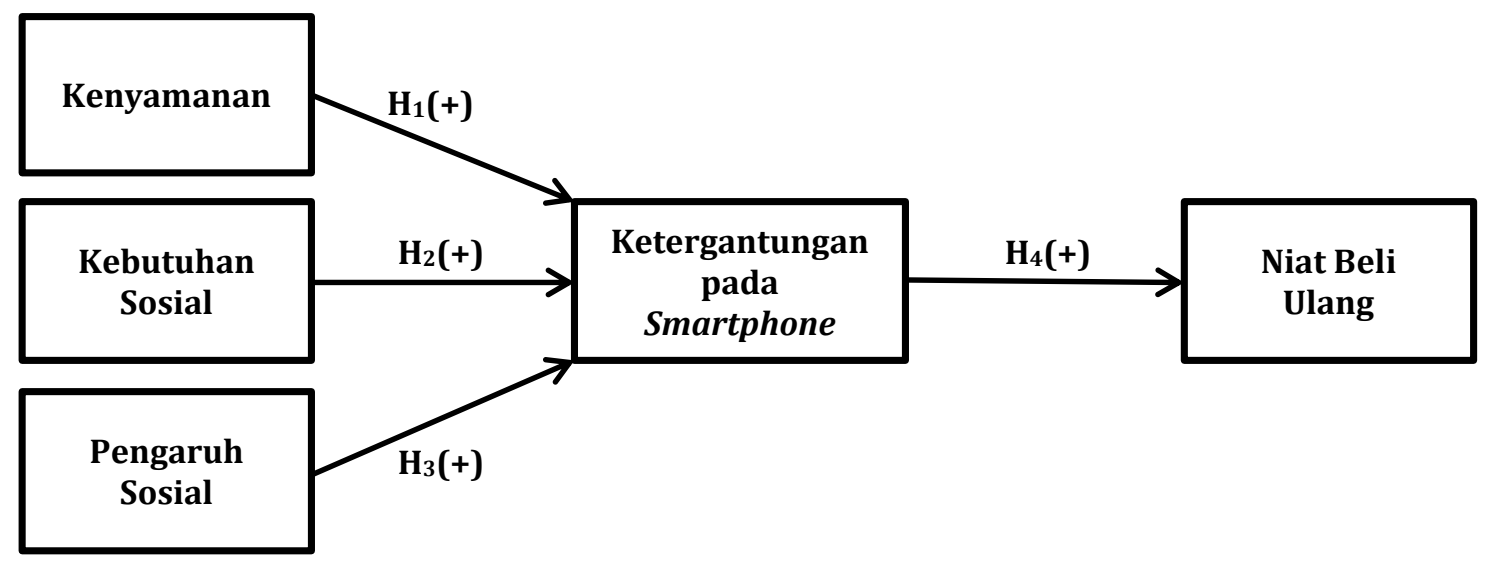

Gambar 2. Model Penelitian 


\section{Metode Penelitian}

\subsection{Populasi dan Sampel}

Populasi dari penelitian ini adalah mahasiswa di Yogyakarta. Sampel yang digunakan sebagai responden adalah mahasiswa aktif di Yogyakarta yang mempunyai smartphone dan termasuk pada kategori dewasa awal (younger adult) yang berusia 18 - 24 tahun (Auter, 2007). Total responden dalam penelitian ini sebanyak 200 orang.

\subsection{Teknik Pengumpulan Data}

Penelitian ini merupakan jenis penelitian kuantitatif yang berupa pengujian hipotesis dengan menggunakan metode survei. Teknik pengambilan sampel menggunakan purposive sampling. Kuesioner penelitian diadaptasi dari penelitian terdahulu. Kenyamanan terdiri dari 5 indikator (Ting et al., 2011), kebutuhan sosial terdiri dari 4 indikator (Ting et al., 2011), pengaruh sosial terdiri dari 4 indikator (Ting et al., 2011), ketergantungan terdiri dari 4 indikator (Ting et al., 2011), dan niat pembelian ulang terdiri dari 5 indikator (Ting et al., 2011; Suki \& Suki, 2013).

\subsection{Uji Validitas, Uji Reliabilitas, dan Teknik Analisis Data}

Pengujian validitas dilakukan menggunakan analisis faktor atau confirmatory factor analysis (CFA) dengan metode rotasi varimax. Suatu instrumen berupa indikator dikatakan valid apabila nilai loading factor $\geq 0,3$ (no cross loading), nilai $K M O \&$ bartlett test $>0,4$, dan nilai signifikansi bartlett's test of sphericity $<0,05$, nilai eigen values tiap komponen loading-nya lebih dari 1 (Hair, et al., 2010). Pengujian reliabilitas dalam penelitian ini melihat nilai cronbach's alpha. Nunnaly (1978) mengungkapkan bahwa indikator dinyatakan reliabel apabila nilai corrected item total correlation $\geq 0,4$ maupun nilai cronbach's alpha $>0,7$. Metode analisis data yang digunakan untuk menguji hipotesis dalam penelitian ini adalah structural equation modeling (SEM) dengan bantuan software LISREL 10.1. Sedangkan ukuran kesesuaian secara deskriptif dinyatakan dalam goodness of fit index.

\section{Hasil dan Pembahasan}

\subsection{Deskripsi Resonden}

Secara keseluruhan total kuesioner yang didistribusikan berjumlah 200 kuesioner. 30 kuesioner untuk menguji validitas dan reliabilitas yang dibagikan kepada responden. Lalu membagikan 170 kuesioner melalui dalam jaringan dengan bantuan aplikasi dari google form, lalu menyebarkan tautan kuesionernya. Sebanyak 96 orang (56\%) responden adalah perempuan, dan sisanya yaitu 74 orang (44\%) responden adalah laki-laki. Sebagian besar berusia 21-24 tahun sebanyak 102 responden (60\%), sedangkan sisanya adalah responden dengan usia antara 18-20 tahun sebanyak 68 responden (40\%). Mayoritas responden menyatakan bahwa lama penggunaan smartphone selama 1-2 tahun sebanyak 59 responden (35\%), lama penggunaan 5-6 tahun sebanyak 58 responden (34\%), dan lama penggunaan 3-4 tahun sebanyak 53 (31\%).

\subsection{Uji Validitas}

Tabel 1 di bawah menjelaskan bahwa konstruk memiliki validitas diskriminan yang baik, dengan tidak adanya cross-loading pada matriks komponen yang dirotasi, dan nilai average variance extracted (AVE) masing-masing variabel penelitian lebih signifikan daripada korelasi kuadrat $\left(\mathrm{R}^{2}\right)$. Dengan demikian, dapat disimpulkan bahwa konstruk masing-masing variabel dalam penelitian ini memiliki validitas konstruk yang baik. 
Tabel 1. Hasil Uji Validitas dan Reliabilitas Konstruk

\begin{tabular}{|c|c|c|c|c|c|c|}
\hline \multirow{4}{*}{ Variabel } & \multicolumn{6}{|c|}{ Validitas Konstruk } \\
\hline & \multicolumn{4}{|c|}{ Validitas Konvergen } & \multicolumn{2}{|c|}{$\begin{array}{c}\text { Validitas } \\
\text { Diskriminan }\end{array}$} \\
\hline & \multirow[b]{2}{*}{$\begin{array}{c}\text { Standardized } \\
\text { Loading } \\
\text { Factor } \\
\geq 0,50\end{array}$} & \multirow[b]{2}{*}{$\begin{array}{l}A V E \\
\geq \\
0,50\end{array}$} & \multicolumn{2}{|c|}{ Construct Reliability } & \multirow[b]{2}{*}{$\begin{array}{c}\text { Rotated } \\
\text { Component } \\
\text { Matrix }\end{array}$} & \multirow[b]{2}{*}{$\begin{array}{c}A V E \\
\stackrel{R^{2}}{ }\end{array}$} \\
\hline & & & \begin{tabular}{|c|} 
Standardized \\
Cronbach's \\
Alpha \\
$\geq 0,7$ \\
\end{tabular} & $\begin{array}{c}\text { Composite } \\
\text { Reliability } \\
\text { (CR) } \\
\geq 0,7 \\
\end{array}$ & & \\
\hline Kenyamanan & $\geq 0,50$ & 0,74 & 0,88 & 0,93 & $\begin{array}{l}\text { no cross } \\
\text { loading }\end{array}$ & Ya \\
\hline Kebutuhan Sosial & $\geq 0,50$ & 0,65 & 0,91 & 0,88 & $\begin{array}{l}\text { no cross } \\
\text { loading }\end{array}$ & Ya \\
\hline Pengaruh Sosial & $\geq 0,50$ & 0,58 & 0,81 & 0,85 & $\begin{array}{l}\text { no cross } \\
\text { loading }\end{array}$ & Ya \\
\hline Ketergantungan & $\geq 0,50$ & 0,47 & 0,86 & 0,78 & $\begin{array}{l}\text { no cross } \\
\text { loading }\end{array}$ & Ya \\
\hline $\begin{array}{l}\text { Niat Pembelian } \\
\text { Ulang }\end{array}$ & $\geq 0,50$ & 0,76 & 0,91 & 0,94 & $\begin{array}{l}\text { no cross } \\
\text { loading }\end{array}$ & Ya \\
\hline Kesimpulan & & & Baik & & Baik & \\
\hline
\end{tabular}

Sumber: Data Diolah (2021)

\subsection{Uji Reliabiltias}

Tabel 1 dan Gambar 3 menunjukkan bahwa semua variabel penelitian yang meliputi kenyamanan, kebutuhan sosial, pengaruh sosial, ketergantungan, dan niat beli ulang, memiliki reliabilitas konstruk yang baik. Dilihat dari nilai cronbach's alpha dan composite reliability $\geq 0,7$. Selain itu, konstruk pada semua variabel penelitian memiliki validitas konvergen yang baik, yang ditunjukkan dengan nilai standardisasi loading factor dan nilai $\operatorname{AVE} \geq 0,5$.

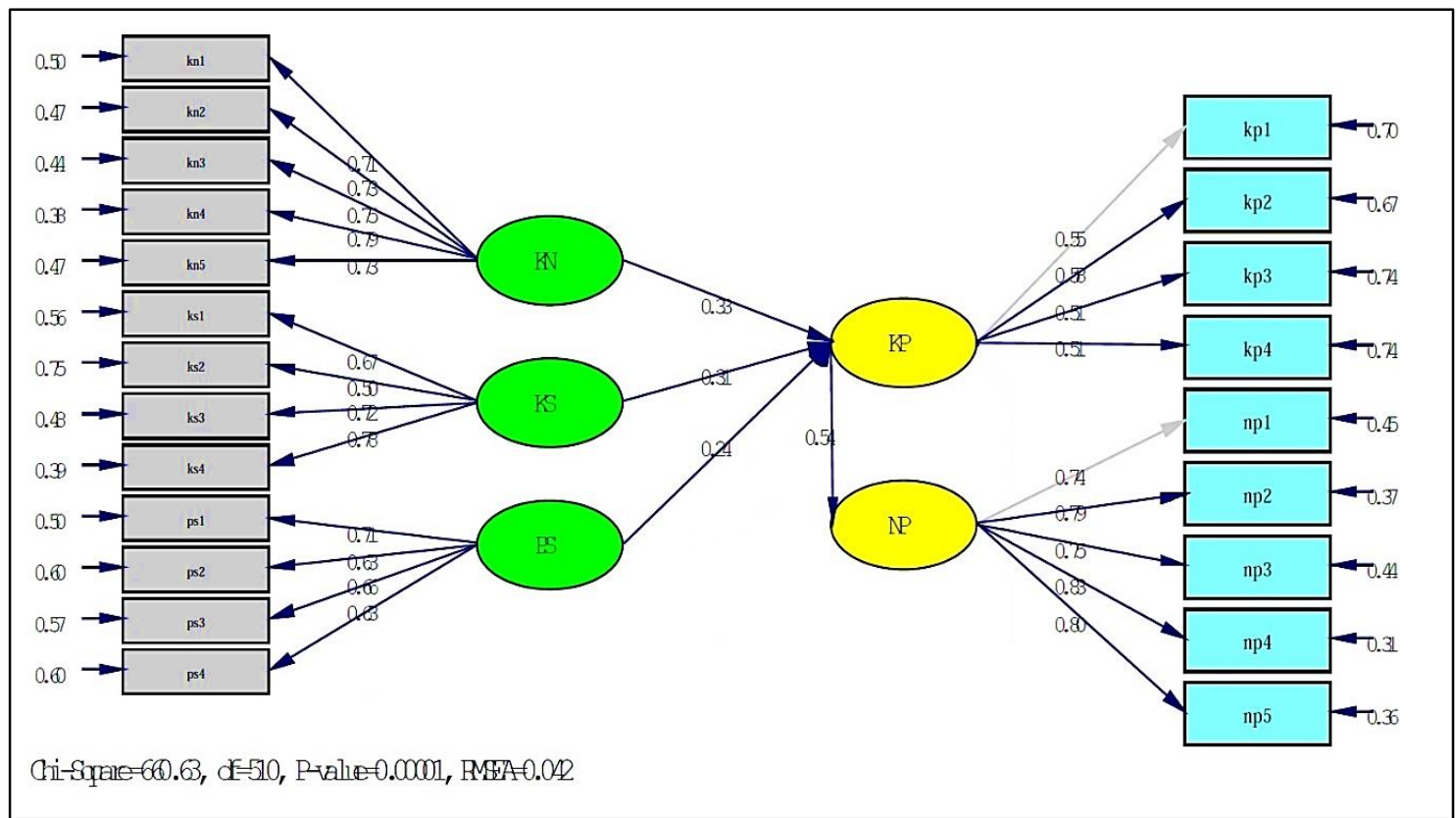

Gambar 3. Standardized Loading Factor 


\subsection{Uji Kecocokan Model}

Tabel 2 menunjukkan bahwa keseluruhan model dalam penelitian ini memiliki nilai incremental fit Index (IFI) lebih besar dari 0,90, nilai non-normed fit index (NNFI) lebih besar dari 0,90, nilai comparative fit index (CFI) lebih besar dari 0,90, dan root mean square error of approzimation (RMSEA) 0,042. Angka-angka tersebut menunjukkan bahwa model penelitian telah memenuhi goodness of fit. Artinya, secara keseluruhan model dengan data memiliki tingkat goodness of fit yang baik.

Tabel 2. Hasil Uji Kecocokan Model

\begin{tabular}{|c|c|c|c|c|c|c|}
\hline & $\begin{array}{c}\text { IFI } \\
(>0,90)\end{array}$ & $\begin{array}{c}\text { NNFI } \\
(>0,9)\end{array}$ & $\begin{array}{l}(0,08 \geq \\
\text { RMSEA } \\
\leq 0,05)\end{array}$ & $\begin{array}{c}\text { CFI } \\
(\geq 0,90)\end{array}$ & $\begin{array}{c}\text { GFI } \\
(\geq 0,90)\end{array}$ & $\begin{array}{c}\text { Goodness } \\
\text { of Fit }\end{array}$ \\
\hline $\begin{array}{c}\text { Full } \\
\text { Model }\end{array}$ & 0,94 & 0,94 & 0 , & 0,94 & 0, & $\mathrm{Ba}$ \\
\hline
\end{tabular}

Sumber: Data Diolah (2021)

\subsection{Uji Hipotesis}

Tabel 3 menunjukkan bahwa pada baris $\mathrm{H}_{1}$ koefisien jalur memiliki arah hubungan positif sebesar 0,33 dan signifikan karena nilai $t=3,41$ lebih besar dari 1,96 sehingga dapat disimpulkan bahwa kenyamanan berpengaruh positif terhadap ketergantungan pada smartphone. Baris $\mathrm{H}_{2}$ koefisien jalur memiliki arah hubungan positif sebesar 0,31 dan signifikan karena nilai $t=3,15$ lebih besar dari 1,96 sehingga dapat disimpulkan bahwa kebutuhan sosial berpengaruh positif terhadap ketergantungan pada smartphone. Baris $\mathrm{H}_{3}$ koefisien jalur memiliki arah hubungan positif sebesar 0,24 dan signifikan karena nilai $t=$ 2,38 lebih besar dari 1,96 sehingga dapat disimpulkan bahwa pengaruh sosial berpengaruh positif terhadap ketergantungan pada smartphone. Baris $\mathrm{H}_{4}$ koefisien jalur memiliki arah hubungan positif sebesar 0,54 dan signifikan karena nilai $t=4,52$ lebih besar dari 1,96 sehingga dapat disimpulkan bahwa ketergantungan pada smartphone berpengaruh positif terhadap niat pembelian ulang.

Tabel 3. Hasil Uji Hipotesis

\begin{tabular}{|c|c|c|c|}
\hline Hipotesis & Nilai Koefisien & Nilai t (>1,96) & Kesimpulan \\
\hline $\begin{array}{c}\text { Kenyamanan } \rightarrow \\
\text { Ketergantungan }\end{array}$ & 0,33 & 3,41 & Diterima \\
\hline $\begin{array}{c}\text { Kebutuhan Sosial } \rightarrow \\
\text { Ketergantungan }\end{array}$ & 0,31 & 3,15 & Diterima \\
\hline $\begin{array}{c}\text { Pengaruh Sosial } \rightarrow \\
\text { Ketergantungan }\end{array}$ & 0,24 & 2,38 & Diterima \\
\hline $\begin{array}{c}\text { Ketergantungan } \rightarrow \text { Niat } \\
\text { Pembelian Ulang }\end{array}$ & 0,54 & 4,52 & \\
\hline
\end{tabular}

Sumber: Data Diolah (2021)

\subsection{Pembahasan}

\subsubsection{Pengaruh Positif Kenyamanan terhadap Ketergantungan pada Smartphone}

Hasil uji hipotesis pertama dalam penelitian ini menunjukkan bahwa kenyamanan berpengaruh positif terhadap ketergantungan pada smartphone. Hasil ini mendukung hasil penelitian dari beberapa peneliti sebelumnya (Ting et al., 2011; Suki, 2013; Hadi, 2020) yang menyatakan bahwa kenyamanan berpengaruh positif dan signifikan terhadap ketergantungan pada smartphone. Hal tersebut memperlihatkan bahwa semakin nyaman seseorang pada saat dan setelah menggunakan smartphonenya, maka seseorang tersebut cenderung semakin tergantung pada smartphone-nya, yang artinya kenyamanan mempunyai pengaruh positif terhadap ketergantungan pada 
smartphone. Hasil pengujian hipotesis pertama dalam penelitian ini juga memperkuat pendapat peneliti terdahulu (Genova, 2010; Suki, 2013; Arif et al., 2016) bahwa konsumen dapat memperoleh informasi yang berguna secara mudah dan cepat melalui internet hanya dengan mengklik sebuah tombol yang ada dalam smartphone-nya, ketika mereka bepergian, beristirahat di rumah, bepergian ke luar negeri, dan sebagainya, sehingga mengakibatkan konsumen menjadi sangat tergantung terhadap smartphone.

\subsubsection{Pengaruh Positif Kebutuhan Sosial terhadap Ketergantungan pada Smartphone}

Hasil uji hipotesis kedua dalam penelitian ini menunjukkan bahwa kebutuhan sosial konsumen berpengaruh positif pada ketergantungan konsumen terhadap smartphone. Hasil penelitian ini sejalan dengan hasil penelitian sebelumnya (Sundar \& Limperos, 2013; Durak, 2019) yang mengungkapkan bahwa kebutuhan sosial berkorelasi positif pada ketergantungan terhadap smartphone. Hal tersebut berarti semakin tinggi kebutuhan sosial seseorang (konsumen), maka semakin tinggi pula ketergantungannya terhadap smartphone. Hasil pengujian hipotesis kedua dalam penelitian ini juga mendukung pendapat dari peneliti terdahulu (Lippincott, 2010; AlShihi et al., 2018; Gasaymeh \& Waswas, 2019) yang menyatakan bahwa kebutuhan sosial merupakan salah satu faktor penentu ketergantungan konsumen terhadap smartphone, karena smartphone telah menjadi jauh lebih fleksibel yang memungkinkan konsumen untuk meningkatkan penggunaannya untuk berkomunikasi dan menjaga hubungan yang terjadi diantara individu.

\subsubsection{Dampak Positif Pengaruh Sosial terhadap Ketergantungan pada Smartphone}

Hasil uji hipotesis ketiga dalam penelitian ini menunjukkan bahwa pengaruh sosial berpengaruh positif terhadap ketergantungan pada smartphone. Hasil ini mendukung hasil penelitian sebelumnya (Tripathi et al., 2016; Shokouhyar et al., 2018) yang menemukan bahwa pengaruh sosial memberikan pengaruh positif pada ketergantungan pada smartphone. Hal tersebut berarti semakin tinggi pengaruh sosial dari pihak lain, maka cenderung ketergantungan terhadap smartphone semakin tinggi. Hasil pengujian hipotesis ketiga ini juga memperkuat pendapat dari peneliti sebelumnya (Yang, 2013; Chen, 2016) yang mengatakan bahwa teman dan anggota keluarga dipandang sebagai pemberi pengaruh sosial yang dianggap penting bagi konsumen dalam mendorong ketergantungan yang lebih besar terhadap smartphone. Hal ini memperlihatkan bahwa pihak lain yang memberikan pengaruh sosial sangat kuat kepada seseorang sampai dia mengalami ketergantungan terhadap smartphonenya, biasanya adalah orang yang sudah dikenal karakternya secara mendalam seperti teman akrab atau bahkan kerabatnya seperti orang tua, kakak, dan adik.

\subsubsection{Pengaruh Positif Ketergantungan pada Smartphone terhadap Niat Pembelian Ulang}

Hasil uji hipotesis keempat dalam penelitian ini menunjukkan bahwa ketergantungan pada smartphone berpengaruh positif terhadap niat pembelian ulang. Hasil ini mendukung penelitian terdahulu yang dilakukan oleh peneliti terdahulu (Ting et al., 2011; Suki \& Suki, 2013; Vahabzadeh et al., 2014; Hadi 2020) yang telah menemukan bahwa ketergantungan terhadap smartphone berpengaruh positif dan signifikan terhadap niat pembelian ulang. Hal ini berarti semakin tinggi ketergantungan terhadap smartphone, maka niat pembelian ulang cenderung semakin tinggi. 


\section{Kesimpulan dan Saran}

\subsection{Kesimpulan}

Penelitian ini berupaya membuktikan argumentasi secara empiris yaitu dengan menguji pengaruh kenyamanan, kebutuhan sosial, dan pengaruh sosial terhadap ketergantungan pada smartphone, serta ketergantungan pada smartphone terhadap pembelian ulang. Kenyamanan berpengaruh positif terhadap ketergantungan pada smartphone. Dengan demikian, hipotesis pertama dalam penelitian ini diterima yang artinya semakin nyaman seseorang dalam menggunakan smartphone, maka semakin tinggi ketergantungannya pada smartphone. Selanjutnya, kebutuhan sosial berpengaruh positif terhadap ketergantungan pada smartphone. Dengan demikian, hipotesis kedua dalam penelitian ini diterima yang berarti semakin tinggi kebutuhan sosial seseorang seperti semakin seringnya seseorang berinteraksi dengan orang lain dapat meningkatkan ketergantungannya pada smartphone.

Pengaruh sosial berpengaruh positif terhadap ketergantungan pada smartphone. Dengan demikian, hipotesis ketiga dalam penelitian ini diterima sehingga dapat dikatakan bahwa semakin tinggi pengaruh sosial yang berasal dari orang lain maupun lingkungan sosial di sekitar seseorang dapat membuat ketergantungan pada smartphone semakin tinggi pula. Begitu pula, ketergantungan pada smartphone berpengaruh positif terhadap niat pembelian ulang. Dengan demikian, hipotesis keempat dalam penelitian ini diterima yang artinya bahwa semakin seseorang tergantung pada smartphone, maka niat pembelian ulang smartphone di masa mendatang juga semakin tinggi.

Hasil penelitian yang telah terbukti secara empiris tersebut mengindikasikan bahwa perilaku ketergantungan seseorang pada smartphone dipicu oleh adanya kenyamanan dalam penggunaan smartphone, tuntutan untuk memenuhi kebutuhan sosial, adanya pengaruh sosial yang berasal dari lingkungan sekitar, seringnya terpapar smartphone dimanapun dan kapanpun, serta adanya aktivitas yang tinggi dari seseorang untuk tetap berada dekat dengan smartphone yang pada akhirnya memicu peningkatan ketergantungan pada smartphone. Selain itu, ada dampak positif yang diakibatkan oleh perilaku ketergantungan pada smartphone adalah niat pembelian ulang di masa mendatang. Hal ini memberikan peluang kepada para produsen maupun pemasar smartphone memperoleh sebanyak-banyaknya konsumen baru maupun konsumen potensial smartphone dengan memanfaatkan faktor pemicu ketergantungan tersebut.

\subsection{Saran}

Meskipun argumentasi penelitian ini terdukung secara empiris, namun penelitian ini masih memiliki beberapa keterbatasan. Beberapa keterbatasan dalam penelitian ini dapat digunakan juga sebagai saran bagi penelitian berikutnya. Pertama, penelitian berikutnya dapat mengaplikasikan longitudinal study karena penelitian ini dilakukan hanya pada satu waktu karena keterbatasan sumber daya peneliti. Kedua, penelitian selanjutnya diharapkan melakukan pengujian yang lebih luas dan komprehensif dengan mengembangkan pendekatan penelitian kualitatif maupun menambahkan beberapa variabel baru terkait perilaku ketergantungan seperti depresi atau ketidakstabilan emosional. Ketiga, penelitian selanjutnya dapat mengganti obyek penelitian yang bukan lagi meneliti tentang smartphone, misalnya jam tangan, laptop maupun barang non elektronik seperti kendaraan bermotor, sepatu, dan lainnya. 


\section{Daftar Pustaka}

Al-Shihi, H., Sharma, S. K., \& Sarrab, M. (2018). Neural Network Approach To Predict Mobile Learning Acceptance. Education and Information Technologies, 23(5), 1805-1824.

Arif, I., Aslam, W., \& Ali, M. (2016). Student's Dependence on Smartphones and Its Effect on Purchasing Behavior. South Asian Journal of Global Business Research, 5(2), 285-302.

Auter, P. J. (2007). Portable Social Groups: Willingness to Communicate, Interpersonal Communication Gratifications, and Cell Phone Use among Young Adults. International Journal Mobile Communications, 5(2), 139-56.

Ball-Rokeach S. J., \& Defleur, M. (1989). Theories of Mass Communication. Logman.

Backer, E. (2010). Using Smartphone and Facebook in A Major Assessment: The Student Experience. e-Journal of Business Education \& Scholarship of Teaching, 4(1), 19-31.

Chen, Y. F. (2013). Mobile Media Dependency: Private Consumption in Public Spaces. In 8th Media in Transition Conference on Public Media, Private Media.

Chen, L., Yan, Z., Tang, W., Yang, F., Xie, X., \& He, J. (2016). Mobile Phone Addiction Levels and Negative Emotions among Chinese Young Adults: The Mediating Role of Interpersonal Problems. Computers in Human behavior, 55, 856-866.

Davis, F. D., Bagozzi, R. P., \& Warshaw, P. R. (1989). User Acceptance of Computer Technology: A Comparison of Two Theoretical Models. Management Science, 35(8), 982-1002.

Durak, H. Y. (2019). Investigation of Nomophobia and Smartphone Addiction Predictors among Adolescents in Turkey: Demographic Variables and Academic Performance. The Social Science Journal, 56(4), 492-517.

Gasaymeh, A. M. M., \& Waswas, D. M. (2019). The Use of TAM to Investigate University Studen's Acceptance of The Formal Use of Smartphones for Learning: A Qualitative Approach. International Journal of Technology Enhanced Learning, 11(2), 136-156.

Genova, G. L. (2010). The Anywhere Office = Anywhere Liability. Business Communication Quarterly, 73, 119-126.

Hadi, A. S. (2020). Pengaruh Paparan, Afinitas, dan Ketergantungan terhadap Perilaku Pembelian Ulang Konsumen. Modus Journals, 32(1), 66-79.

Hadi, A. S. (2020). Analisis Faktor Kenyamanan dan Ketergantungan Mahasiswa pada Smartphone yang Mengakibatkan Stress. Jurnal Bisnis Darmajaya, 6(2), 37-47.

Hahn, J. (2010). Information Seeking with Wikipedia on Ipod Touch. Reference Service Rewiew, $38(2), 284-298$.

Hahn, K. H., \& Kim, J. (2013). Salient Antecedents of Mobile Shopping Intentions: Media Dependency, Fashion/Brand Interest and Peer Influence. Journal of Global Fashion Marketing, $4(4), 225-246$. 
Hair J. R., Josep F., William C. B., Barry J. B., \& Rolphe E. A. (2010). Multivariate Data Analysis Seventh Edition. Pearson Prentice Hall.

Harun, A., Soon, L. T., Kassim, A. W. M., \& Sulong, R. S. (2015). Smartphone Dependency and Its Impact on Purchase Behavior. Asian Social Science, 11(26), 196.

Ho, S. S., Liao, Y., \& Rosenthal, S. (2015). Applying The Theory of Planned Behavior and Media Dependency Theory: Predictors of Public Pro-Environmental Behavioral Intentions in Singapore. Environmental Communication, 9(1), 77-99.

Hovart, A. T. (1989). Coping with Addiction.

Hudson, A. (2010). Measuring The Impact of Cultural Diversity on Desired Mobile Reference Services. Reference Research Review, 38(2), 1-13.

Jang, K., \& Baek, Y. M. (2019). When Information from Public Health Officials is Untrustworthy: The Use of Online News, Interpersonal Networks, and Social Media during The MERS Outbreak in South Korea. Health Communication, 34(9), 991-998.

Jung, J. Y. (2017). Media Dependency Theory. The International Encyclopedia of Media Effects, 110.

Keaveney, S. M., \& Parthasarathy, M. (2001). Customer Switching Behaviour in Online Services: An Exploratory Study of The Role of Selected Attitudinal, Behavioural, and Demographic Factors. Journal of the Academy of Marketing Science, 29(4), 374-390.

Lee, J., \& Choi, Y. (2018). Informed Public Against False Rumor in The Social Media Era: Focusing on Social Media Dependency. Telematics and Informatics, 35(5), 1071-1081.

Lian, L., You, X., Huang, J., \& Yang, R. (2016). Who Overuses Smartphones? Roles of Virtues and Parenting Style in Smartphone Addiction among Chinese College Students. Computers in Human Behavior, 65, 92-99.

Lippincott, J. K. (2010). A Mobile Future for Academic Libraries. Reference Services Review, 38(2), $1-20$.

Liu, Q., Wu, J., Zhou, Z., \& Wang, W. (2020). Parental Technoference and Smartphone Addiction in Chinese Adolescents: The Mediating Role of Social Sensitivity and Loneliness. Children and Youth Services Review, 118, 105434.

Mason, W. A., Conrey, F. D., \& Smith, E. R. (2007). Situating Social Influence Processes: Dynamic, Multidirectional Flows of Influence within Social Networks. Personality and Social Psychology Review, 11, 279-300.

Mayasari, I. (2010). Mencermati Perilaku Smarthphone Niacs. Marketing, Edisi Minggu Bisnis Indonesia, pp.13.

Nawi, N. W. M., Alsagoff, S. A., Osman, M. N., \& Abdullah, Z. (2020). New Media Use among Youth in Malaysia: A Media Dependency Theory Perspective. PalArch's Journal of Archaeology of Egypt/Egyptology, 17(9), 836-851. 
Ognyanova, K., \& Ball-Rokeach, S. J. (2015). Political Efficacy on The Internet: A Media System Dependency Approach. In Communication and Information Technologies Annual. Emerald Group Publishing Limited.

Oliver, R. L. (1999). Whence Consumer Loyalty. Journal of Marketing, 63(4), 33-44.

Park, W. K. (2013). The Internet and Media Dependency: Re-examination of Y2K Crisis Phenomena from Media Ecological Perspective. Asian Communication Research, 10(1.2), 5257.

Pusparisa, Y. (2020). Pengguna Smartphone diperkirakan Mencapai 89\% Populasi pada 2025.

Rahim, A., Safin, S. Z., Kheng, L. K., Abas, N., \& Ali, S. M. (2016). Factors Influencing Purchasing Intention of Smartphone among University Students. Procedia Economics and Finance, 37, 245-253.

Raskin, R. (2006). Facebook Faces Its Future. Young Consumers, 4(1), 56-58.

Rice-Lincoln, S. (2011). 2012 Promises to Be the Year of Mobile Marketing.

Schiffman L. G., Kanuk, L. L., \& Wisenbut, J. (2009). Consumer Behavior. Pearson.

Shokouhyar, S., Siadat, S. H., \& Razavi, M. K. (2018). How Social Influence and Personality Affect User's Social Network Fatigue and Discontinuance Behavior. Aslib Journal of Information Management, 70(4), 344-366.

Statista Research Department. (2020). Pengguna Smartphone diperkirakan Mencapai 89\% Populasi pada 2025.

Stephen, K. K., \& Davis, J. (2009). The Social Influences on Electronic Multitasking in Organization Meetings. Management Communication Quarterly, 23(1), 63-83.

Suki, N. M. (2013). Student's Dependence on Smart Phones: The Influence of Social Needs, Social Influences, and Convenience. Campus-Wide Information Systems.

Suki, N. M., \& Suki, N. M. (2013). Dependency on Smartphones: An Analysis of Structural Equation Modelling. Jurnal Teknologi (Social Sciences), 62(1), 49-55.

Sundar, S. S., \& Limperos, A. M. (2013). Uses and Grats 2.0: New Gratifications for New Media. Journal of Broadcasting \& Electronic Media, 57(4), 504-525.

Thamrin, S. D. (2003). Studi Mengenai Proses Adopsi Konsumen Pasca Masa Tayang Iklan Produk Xon-Ce Di Surabaya. Jurnal Sains Pemasaran Indonesia, 2(2), 141-154.

Tian, L., Shi, J., \& Yang, Z. (2009). Why Does Half The World's Population Have A Mobile Phone? An Examiniation of Consumer's Attitudes to Mobile Phones. Cyber Psychology and Behaviour, 12(5), 513-516.

Tikkanen, I. (2009). Maslow's Hierarchy and Pupil's Suggestions for Developing School Meals. Nutrition and Food Science, 39(5), 534-543. 
Ting, D. H., Lim, S. F., Patanmacia, T., Low, C. G., \& Gay, C. K. (2011). Dependency on Smartphone and The Impact on Purchase Behavior. Young Consumers, 12(3), 193-203.

Towner, T., \& Lego Munoz, C. (2016). Boomers Versus Millennials: Online Media Influence on Media Performance and Candidate Evaluations. Social Sciences, 5(4), 56.

Tripathi, V., Shukla, S. M., Saran, P. K., \& Kumar, S. (2016). Purchase Intention Towards EcoFriendly Electronic Products While Incorporating Mediating Influence of Brand Image. IJABER, 14(12), 8335-8348.

Vahabzadeh, S., Duneghe, S. S., \& Khachoei, T. A. (2014). A Study of the Factors Influencing Dependency and Its Effect on the Purchase Behavior of the Iranian Consumers of Smartphones. Switzerland Research Park Journal, 103(2), 1120-1132.

Wulandari, R. (2015). Hubungan Antara Kontrol Diri dengan Kecanduan Game Online pada Remaja di Warnet Lorong Cempaka Dalam Kelurahan 26 Ilir Palembang, Jurnal Fakultas Psikologi Universitas Bina Dharma Palembang, 1-15.

Yang, H. C. (2013). Bon Appétit for Apps: Young American Consumer's Acceptance of Mobile Applications. Journal of Computer Information Systems, 53(3), 85-96.

Zhang, X., \& Zhong, Z. J. (2020). Extending Media System Dependency Theory to Informational Media Use and Environmentalism: A Cross-National Study. Telematics and Informatics, 50, 101378. 